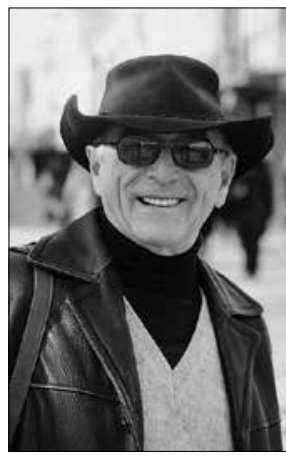

https://doi.org/10.24101/logos.2018.66

Gauta 20181012

\title{
ALGIS MICKŪNAS
}

Ohajo universitetas, JAV

Ohio University, USA

\section{DIALOGAS IR PASAULIS \\ Dialogue and World}

\author{
SUMMARY
}

Philosophy was born in the form of dialogue: in many cases the works of Plato are titled the Dialogues of Plato. Dialogue means that any understanding is dependent on a person talking to another person about something, some topic or issue. Yet talking to someone also includes the views of many others. To speak to someone about gravity includes Newton and other scientists as dialogical partners extending the discussion into a "poly-logical" depth. In this sense, each dialogical person is located in a field of "poly-centric" awareness, where each claim is limited by other claims and at the same time extended by others. Meanwhile a monologue is an assumption of a position which claims to be absolute and any contribution by others is a priori subsumed by such an absolute position. The latter "explains" everything that the other might say and thus deny the relevance of the other's awareness. In this case, there is only one, unsituated voice, silencing all others. In the essay there is an argument showing how monologue cannot maintain its position.

\section{SANTRAUKA}

Filosofija gimè dialogo forma. Platono kūrinius net ir vadiname "Platono dialogais“. Dialogas atveria tarp asmenų kylanti supratimą apie jiems rūpimą klausimą ar temą. Tačiau šis pokalbis numato ir daugeli kitų nuostatų. Pavyzdžiui, kalbėdami apie gravitaciją, prisimename Newtoną ir kitus mokslininkus, kurie tarsi dalyviai papildo ir pratęsia tokị dialogą. Kitaip tariant, diskusija igyja poli-loginės gelmès. Šiuo požiūriu visi dialoge dalyvaujantys asmenys kartu dalyvauja ir poli-centriškame suvokime, kur kiekvienas teiginys yra ir ribojamas, ir kartu praplečiamas kitų dalyvių nuomonėmis. O monologiška nuostata bando įtvirtinti savo absoliutumą ir a priori redukuoti bei sumenkinti bet kokị kitų indèlį. Tokia nuostata ne tik "paaiškina“, ką ir kaip kiti gali pasakyti, bet ir paneigia "kito" suvokimą. Taip steigiama nuostata, kuri nutildo visas kitas. Straipsnyje parodoma, kad tokia monologiška nuostata negali išsilaikyti.

www. bernardinai.lt nuotrauka.

RAKTAŽODŽIAI: policentriškas dialogas, polilogas, tarpcivilizacinis dialogas, integrali sąmonė.

KEY WORDS: polycentric dialogue, polylogue, dialogue among civilizations, integral consciousness. 
A $t$ the outset it must be emphasized that dialogical world is intersubjective and is one major way of resolving the protracted controversy between the proponents of the priority of individual over society and those who claim the supremacy of society. In the first instance, society is regarded as a sum of separate and indeed solipsistic individuals having solely antagonistic relationships, while in the second, the individual is a conjunction of social, events wherein society (at times interpreted in the form of institutions) is the defining dimension. Meanwhile, the composition of dialogue has to be understood as prior to and founding individualism and societism. First, in dialogue the other is not present as an object, a given entity, a mind inhabiting a body, but as a copresence engaged in a common venture. One speaks with someone about something, some topic, concern, subject matter, prior to regarding the other as a subject or an object. The commonality, here, is a subject matter in which WE are engaged, which WE confront, dispute, or agree upon. There is granted an orientation toward something with an orientation of a self to the other.

Second, the notion of sender-messagereceiver must be modified away from a sequence of activity-passivity, where the sender acts, while the receiver accepts the message. Rather, it is a complex process of the establishment of both sender and receiver in a way that they both are contemporaneously active-passive as a mutual articulation and interrogation of a subject matter. Each partner founds the dialogue and in turn is founded by it.
There is neither the priority of the individual, as the ultimate foundation, nor of the dialogical WE as the more encompassing. They are mutual and can be regarded analogously to a melody: each note is an individual and without it there would be no melody, but the melody also allows a note to have its say as position in the melody. Change in either one is mutually change in the other.

Third, the dialogical partner is not merely the currently copresent other, but the others whose orientations toward the world, their perceptions of the topic, the subject matter, are equally copresent. The books I read, the conversations I had with others - perhaps long forgotten comprise an extension of my perceptions and constitute a polycentric-polylogical field. I perceive with the perceptions of the others, perceptions that contest, extend, and modify my own regard of a given subject matter. The same is true of my current dialogical partner; she too is founding of and founded by a polycentric field, and in our dialogue, we mutually involve our polycentric awareness and hence extend our polycentric participation. This also constitutes the basis for transcendence of one's own limitations and resultantly for openness and freedom. Without the other, and without our being copresent in a polycentric field, we would lack the transcending movement.

Fourth, polycentric polylogue defies the traditional notions of sequential history; polylogue constitutes a field of temporal depth wherein the "past" partners are not passive, but participate equally in articulating, challenging, and 
interrogating a specific issue, topic, or subject matter. Thus, it is quite normal to say, for example, that for the Egyptians humans were not categorized in terms of some presumed racial features, but in accordance with hierarchies of social positions and tasks. Of course, the focus of our polylogue is the human, while the others, the Egyptians, open and extend our perception by showing our own limitations and positionality. Here, their perceptions contest actively our own perceptions. At the polylogical level we are constantly decentered from our limitations even when we would reject the others perceptions of a given subject matter. Indeed, the very preoccupation with rejection, the efforts to demonstrate the inadequacy, the mistaken understanding, and downright error, shows the extraordinary credence and copresence of the other.

Fifth, the polylogical copresence of the other not only decenters mutually absolute positionalities, but also constitutes the initial awareness of human situatedness as well as a reflective selfidentification each through the other. It could be argued that polylogical field comprises the domain of inter-positional reflexivity such that one recognizes oneself only due to the difference from the other in modes of awareness of a subject matter. This is the transparency principle: I know myself to the extent that I reflect from the other, from the how she articulates a specific theme. I see myself through the different perceptions offered by the other that connect us by way of a common theme, task, subject matter, and allows us our recog- nition of our own positions. Another aspect of this morphology must be mentioned in order to avoid misunderstandings inherent in the efforts to objectify the other. Even if we engage in a dialogue about the other, we shall find that she cannot be understood apart from her perceptions of something, of some concerns inherent in her world. We shall understand her only to the extent that she is engaged in some task or concern, and thus is an aspect of our own polycentric field. After all, to discuss Virginia Wolf, is to discuss her views about something and thus introduce her as our polylogical partner. Even if we were so crude as to intrude into her "private feelings" we would still understand them as "feelings about something." She, as well as we, are comprehensible only with respect to the world we address, contest, and share in our different ways. An allencompassing, undifferentiated, homogeneous thesis would not be recognizable, would not possess an identity, and would cease to be polylogical; it would be a divine speaking without any copresence of the other. It would be a denial of the other's existence as copresence through difference. That such divine positions are assumed is obvious from numerous examples across cultures and even within specific cultural institutions. It behooves us, therefore, to explicate such positions which, while dramatically paradoxical due to their emphasis on the other, they attempt to abolish the other's existence.

We know that there are numerous institutions in cultures, such as scientific theories or ideological prejudgments 
which purport to "explain" everything and specifically the other. Not all such theories need be explored; we must disclose their common principles that will inhere in such explanations. In turn, we shall not rank such theories with respect to their "higher" status in a given culture, not because we wish to insult the adherents to such theories, but due to the comparative nature that seeks essential commonalities. To speak in principle, all theories that posit an inevitable cause for and outcomes of human actions engage in homogenization and thus a denial of human presence as a diversity. In the final analysis there are the mechanical, universal laws, forces clashing in the cosmic night, childhood violations, historical market forces, that speak. Here one cannot claim a situated, responsible, polylogical, contesting, limited but open human presence. In principle, this is an abolition of the subject in favor of an object as a product of causes, an engagement in monological and all-encompassing presence that subsumes and silences the other.

The situated, polylogical individual, is replaced by an abstract set of factors: the human is subject to the force of institutions, such as mass media, that are deemed to be in a position to posit the individual as an object and to determine her course. In brief, the other does not exist as a polylogical other, but is an object without any situational perception and identity by virtue of polylogical differentiation. What is of note is that the speakers proclaim these theses - even if for a moment - ex catedra, from a homogeneous position, without a reflective moment that such a position is an aspect of their own polylogical differentiation from other positions. They claim to be unsituated, apart from, and untainted by the very institutions or factors which they posit as grounds for all explanations. This is their dramatic paradox: peoples are dominated by institutions, by causes, but our proclamations are from a position of unaffected privilege. We are the subject and our discourse is homogeneously absolute. The other, here, does not exist as a speaking, dialogical subject. One specific result of this homogeneity is the tacit assumption that the other cannot be held responsible; she is innocent. Indeed, in some discourses, she may be defined as a victim, and indeed an innocent victim.

Yet an unavoidable reflexivity comes into play, and in principle. The very claim to innocence and victimization is a position, differentiated from other positions in a polilogical field of claims and counter-claims, accusations and excuses. The first moment of such a polilogical interplay is the pointing out that the objectifiers of the other must either belong to the same explanation and hence cannot claim to be responsible subjects, or they are cynical. The second moment appears in all cases when the victimized proclaim their innocence and accuse the other as the victimizer. The victimized joyfully-sorrowfully exhibits the scars of being "crucified" and oppressed and, therefore, of having a universal moral authority by dint of their suffering, to judge all others. What is characteristic of these claims, as a third moment, is equally an abstract universal posture: the Ger- 
mans did this to us, the Soviets have crucified us, the Japanese owe us an apology, Eurocentrism is a neo-colonial privileged invasion. The fourth, moment shows that the other, the colonizer, the oppressor, is not another at all, not a polylogical partner, but a monstrous object, an anonymous blind force bereft of human features.

Here the denial of the polylogical other, in the other's very forceful presence, takes on a dual abstraction. The oppressor sees the other as a lesser being, and if this view is pushed to the limit, the other is denied human existence. The other belongs to a race that cannot be characterized as human; she is on a lower level of evolution and per force is best suited for subservient tasks. Here the oppressor, the racist, denies his own positionality and polylogical situatedness and regards the other from totalized position. The other may offer her deeds, achievements, trajectory of her life, but the racist has presumed the sole and true standards such that the other can never offer adequate evidence that she has a right to human existence. If her deeds, history, achievements, as correlations to the world are excluded, then she is left as a pure body, an entity that does not resemble anything human. But the ethnically or racially oppressed are equally exposed to the same logic. They must regard the oppressor in terms of decontextualized abstraction. The oppressor, the racist is equally lacking in human characteristics. He lacks conscience, is a brutish barbarian and, as all lower creatures, is a predator. Moreover, he is incapable of providing for his own needs; all his possessions stem from theft. All his deeds, his life's achievements, do not belong to him but to those he oppresses and exploits. He is a body bereft of significance, a greedy biochemical mechanism. This too constitutes a non-polilogical attitude and establishes an unsituated gaze toward the other. On both sides the polilogical transcendence and hence human situated and yet decentered freedom is abandoned.

Such a dual abstraction, indeed disembodied reification, is extended to include various moves toward liberation from racism, ethnocentrism and their modes of oppression. In this case, those to be liberated must be passively ideal, voiceless. They cannot have any faults; any faults are the results of oppression. In this sense the oppressors are completely faulty, corrupting and immoral. Unless one grants the oppressor a status of pure reification, one will have to lend him a position of subjectivity, intentionality and responsibility for his morally unjustifiable racist activities. The ideal oppressed, the colonized, the exploited, will have to surrender the status of a subject, the being of intentionality, of making decisions. In order to retain their purity and innocence, they will have to parade their passivity, their life as death as the ultimate virtue. It is an ideality that is equally without position, although it may proclaim that it is the highest bearer of moral virtues. This abolition of their own situated dialogical transcendence abolishes their own humanity.

This type of institutional racism is, at this level, now regarded as a universal logic. It is a standard that decides the 
other's status as belonging to either a race or an ethnic group that is inadequate. The inadequacy may be regarded as either scientifically demonstrated fact, or as a result of social, cultural superstitions. Thus, for example, the women of the others have no intelligence concerning their sexuality, overproductivity, and the ability to use scientific means for birth control. To speak functionally, they are inefficient with respect to the good life. If it is not their intelligence, then at least their cultures are flawed. Thus, they must be extricated from their "irrational superstitions" and made to function in a technocratic, "objective" environment, constituted by the racially superior intelligence. Their culture will have to be surrendered as the faulty system of irrational, subjective beliefs that has hindered the other to enter into objective "world history." Of course, surrendering the faulty culture is not a guarantee that the other, excised from her dialogical setting, is adequate to function in the non-dialogical context of institutionalized science and social technocracy. At best, the other will be placed in tasks requiring no intelligence. The racist will have to be benevolent, have some pity to the lesser others, so well paraded in THE BELL CURVE. There is proffered UNIVERSAL EVIDENCE as to the objective embodiment of material inferiority of the racial other. In this sense, the denial of employment, education, and the "normal" social anemities will be the denial of her right to existence, will be equivalent to her death.

The institutionalized racism and ethnicism will not regard these denials as violations, but as an objective necessity: there is nothing you can do for, or with these others. The proclamation, in principle, is this: neither the institutionalized racism nor the other can do anything about objective, genetic facts. The latter legitimate the tacit assumption of the superiority of the racist institutions. The very fact that "we discovered" the ultimate explanation of all human capacities, through our technology, is a proof that we are not only the best, the presence of true humanity, but also that we have a "manifest destiny" to manage the affairs of the others. This very claim confirms the racist regard that the other is a priori disfunctional, inefficient, an irrational child. But, as noted above, this racist attitude, vis a vis the scientific technocratic social world, is equally bereft of the dialogical human presence. Indeed, he too is a result of the same genetic laws that rob him of any claim to humanity. He is a subjected subject, equally explainable by such impartial universal laws, that leave no room to claims concerning HIS achievements. After all, genetic rules have no "personalities" and ply their trade without any regard to the dialogical, intersubjective human world. What this suggests is that the racist, pegging himself on institutionalized science, abolishes his right to claim any superiority.

There are also the components of institutionalized cults, tacitly legitimating racism by proclaiming THE TRUTH of the chosen peoples. Regardless who makes such a proclamation, the other must be outside of the chosen circle and, minimally speaking, on the verge of evil. This holds despite the fact that there are 
numerous cults, such as fundamentalist Christians, Muslims, Jews, hindus, who may vie for outdoing one another's claim to supremacy and culto-centric racisms. Each holds its position to be the sole and ultimate truth and may, at times, hold members of other similar cults as racially inferior, suited, at best, for conversion, subservience, or extinction. Indeed, numerous confrontations today occur among cultic groups, each intent in converting all others into its own proclamations and imposing the latter on all publics. This is well known under the essential rubric of HOLY WAR, ranging from war with words through "divinely inspired" murder. The suggestion, here, is that despite surface variations among cultic groups, the murder of the other is an extension of the killing, attacking, by words. We must remind ourselves that for cults words are not discursive, dialogical, but rather magical deeds, identical with creation and destruction. A prayer, after all, is a power for the unleashing of events. In this sense, murder of the other is not an individual act, but an embodiment of divine speaking, of carrying out the "word" of a god. Indeed, the other, the enemy of the word, is radically important as the worthy enemy, as the embodiment of evil itself, calling one to destructive acts against the other. The current language of those who carry out THE WORD is replete with the terminology of good and evil, with demonization that calls for the cleansing of the world from the other, with blatant exclusion of the other from any consideration as a dialogical partner, and with the presumption of a monological speech, coextensive with the ultimate word of a cult's divinity.

At the outset, the above delimitations suggest an inevitable "logic." The monological abstractions, universalities, in their exclusion of the other, revert, constantly to the positionality, specificity, of including the other as the most important aspect of their logic. While denying, these logics allow the other's freedom and indeed transcendence of the racist's claims to universality. By freedom is meant the resiliency, the constant requirement to deal with, include the other as never completely subjectable to the racists universality. After all, the history of racism reveals most diverse, most devious, cunning, banal, sublime and "scientifically sober" efforts to ban, kill, destroy the transcendence of the other. Hence, even the institutionalized modes of racism, that spread their message among collectivities, do so precisely at the level which admits the uncontrollable other, the impossibility of subjecting her completely to institutionalized racism. The spread is a general attitude which sees in every black all blacks, in the lynching of him, a lynching of all of them. Here, the dialogue is reversed, such that the universal rationality of an institution, claiming to dispel the darkness of cultural superstitions, becomes a promoter of another superstition, of an aura that surrounds an entire group. Hence, when the racist reacts to an individual, he does not do so rationally, reacting to this individual, but to a "black, much too black" other. What enters here initially is the notion that racism, such as white racism, is a white problem in 
the white dialogue. Here, the term "dialogue" can no longer be avoided, since the white constantly address the questions concerning the solution of "black problems." The latter cannot be solved by the blacks, since by institutional definitions, they do not possess sufficient human intelligence. Hence, they must be saved from themselves. The white, in this racial context, cannot be offered sal-

\section{Literature}

Mickunas, A. 2012. The Divine Complex and Free Thinking (Critical Bodies) ISBN 9781612891026 (978-1-61289-102-6) Hampton Pr.

Mickunas, A. 1975. Exploring Phenomenology: A Guide to the Field and Its Literature ISBN 9780838901779 (978-0-8389-0177-9) American Library Association.

Mickunas, A., Scudder R. John. 1985. Meaning, Dialogue and Enculturation: Phenomenological vation. He can either help, destroy, or get out of the way of, the black; yet at the end any contemplated option is not for the white. Even in cases of white persons seeking racial justice for the other, knows intimately that racial justice is not for him, since he invented this problem of justice. In this sense, to be a white racist is either to be condemned by the other, or to condemn oneself.

Philosophy of Education ISBN 9780819147066 (978-0-8191-4706-6). Rowman \& Littlefield.

Pilotta, J., Mickunas, A. 1997. Technocracy Vs. Democracy: Issues in the Politics of Communication (Hampton Press Communication Series) ISBN 9781572731066 (978-1-57273-106-6).

Gebser, J. 1985. The Ever-Present Origin. Translated by Mickunas, A., Barstad, N. ISBN 9780821402191 (978-0-8214-0219-1). Ohio Univ Pr. 